\title{
Systematic and historical biogeography of the Bryconidae (Ostariophysi: Characiformes) suggesting a new rearrangement of its genera and an old origin of Mesoamerican ichthyofauna
}

\author{
Kelly T Abe, Tatiane C Mariguela, Gleisy S Avelino, Fausto Foresti and Claudio Oliveira*
}

\begin{abstract}
Background: Recent molecular hypotheses suggest that some traditional suprageneric taxa of Characiformes require revision, as they may not constitute monophyletic groups. This is the case for the Bryconidae. Various studies have proposed that this family (considered a subfamily by some authors) may be composed of different genera. However, until now, no phylogenetic study of all putative genera has been conducted.

Results: In the present study, we analyzed 27 species (46 specimens) of all currently recognized genera of the Bryconidae (ingroup) and 208 species representing all other families and most genera of the Characiformes (outgroup). Five genes were sequenced: 16SrRNA, Cytochrome $b$, recombination activating gene 1 and 2 and myosin heavy chain 6 cardiac muscle. The final matrix contained 4699 bp and was analyzed by maximum likelihood, maximum parsimony and Bayesian analyses. The results show that the Bryconidae, composed of Brycon, Chilobrycon, Henochilus and Salminus, is monophyletic and is the sister group of Gasteropelecidae + Triportheidae. However, the genus Brycon is polyphyletic. Fossil studies suggest that the family originated approximately 47 million years ago $(\mathrm{Ma})$ and that one of the two main lineages persisted only in trans-Andean rivers, including Central American rivers, suggesting a much older origin of Mesoamerican ichthyofauna than previously accepted.

Conclusion: Bryconidae is composed by five main clades, including the genera Brycon, Chilobrycon, Henochilus and Salminus, but a taxonomic review of these groups is needed. Our results point to a possible ancient invasion of Central America, dating about $20.3 \pm 5.0 \mathrm{Ma}$ (late Oligocene - early Miocene), to explain the occurrence of Brycon in Central America.
\end{abstract}

Keywords: Characiformes, Bryconidae, Evolution, Phylogeny, Systematics

\section{Background}

The order Characiformes contains approximately 2000 species distributed among 23 families, with 19 exclusively Neotropical families and four exclusively African families [1-3]. The order comprises one of the largest freshwater fish radiations. Among characiform genera, Brycon is one of the most speciose, containing 42 species [4,5]. Members of this genus occur from southern Mexico to Panama, across the trans-Andean South American river basins from northern Peru to the Maracaibo system in Venezuela, in all

\footnotetext{
* Correspondence: claudio@ibb.unesp.br

Departamento Morfologia, Instituto de Biociências, UNESP - Universidade Estadual Paulista, Botucatu, São Paulo, Brazil
}

major river drainages in cis-Andean South America, and in most Atlantic and Caribbean coastal river basins [4]. Brycon species are medium- to large-sized fishes, with a maximum standard length from $15 \mathrm{~cm}$ (Brycon pesu) to approximately $70 \mathrm{~cm}$ (Brycon orbygnianus and Brycon amazonicus). Brycon species are important food fishes throughout Central and South America [4], with catches estimated to approximately 5,100 tons for the year 2007 in Brazil [6].

Despite their wide distribution, species diversity, and commercial importance, the taxonomy of the Bryconidae remains unclear. Species in Panama and the trans-Andean rivers of northern South America were extensively studied 
by Eigenmann [7], Hildebrand [8] and Dahl [9]. In contrast, the taxonomy of Brycon species in the cis-Andean river basins was revised by Lima [10] in an unpublished master's thesis. Lima [4] published a taxonomic synthesis of the Bryconinae, which, in addition to the genus Brycon, included two monotypic genera: Chilobrycon Géry \& Rham, 1981 and Henochilus Garman, 1890.

The phylogenetic relationships within the Bryconidae have been the subject of several studies; however, a detailed hypothesis of the relationships among its species and with other Characiformes is absent. Regan [11] was the first author to propose a relationship between Brycon and Chalceus. In the same study, he further proposed that Salminus and Hystricodon (=Exodon) were related to Brycon. Eigenmann [12] proposed the classification of the subfamily Bryconinae, including the genera Brycon and Chalceus. Géry [13] proposed that the Bryconinae instead be classified as the subfamily Chalceinae; however, in 1972, Géry [14] followed the Bryconinae classification and divided the subfamily in three tribes: Bryconini, Triportheini and Salminini. The same classification scheme was used in Géry's [15] seminal book on characiforms.

In a comparative osteological study of Brycon and Salminus, Roberts [16] suggested that the apparent similarities between them may reflect the primitive position of Brycon. Uj [17] proposed a new classification, the family Bryconidae, which included Brycon, Chalceus, Catabasis, Lignobrycon, Salminus, Triportheus, Chilobrycon and Bryconexodon. Mirande [18] recognized the subfamily Bryconinae, comprised of Brycon, Triportheus, Chilobrycon, Henochilus, and Lignobrycon. The latter three genera were not studied by Mirande [18]; however, whereas Chilobrycon and Henochilus are recognized as closely related to Brycon [4], Lignobrycon appears distinct, and the absence of representatives of this genus may be responsible for the unusual result reported by the author. Molecular data [1,19-21] supports the close relationship between Brycon and Salminus proposed by Uj [17]. In the broadest molecular phylogenetic study of the Characiformes published to date, Oliveira et al. [1] analyzed specimens of Brycon, Henochilus and Salminus and recognized them as a monophyletic group, the family Bryconidae.

Given the importance of the Bryconidae among the Characiformes, as stated above, two mitochondrial and three nuclear genes of representatives of all genera of this family, along with representatives of all other Characiformes families [as defined by 1], were analyzed in the present study to formulate a hypothesis of the relationships among species and genera of the Bryconidae and between this family and the other Characiformes. In addition, a time-calibrated tree was constructed to investigate the temporal relationships between the origin of Bryconidae groups and the main geological events in South America.

\section{Methods}

\section{Selection of taxa and delineation of the ingroup and outgroup}

The ingroup was composed of 46 specimens including 27 species of all four recognized genera of the Bryconidae (Table 1, Figure 1). To replace the Bryconidae into the evolutionary tree of the Characiformes we used the matrix employed by Oliveira et al. [1] in their broad study of Characidae relationships, including 208 samples representing all Characiformes families (Additional file 1). All specimens for this study were collected in accordance with Brazilian laws under a permanent scientific collection license in the name of Dr. Claudio Oliveira (IBAMA-SISBIO, 13843-1). Additionally, this survey was carried out in strict accordance with the recommendations for the National Council for Control of Animal Experimentation and Federal Board of Veterinary Medicine. The studied material was deposited in the Laboratório de Biologia e Genética de Peixes (LBP), Instituto de Biociências, Universidade Estadual Paulista, Botucatu, Sao Paulo, Brazil.

\section{Molecular data collection}

Total DNA was extracted from ethanol-preserved muscle samples using the DNeasy Tissue Extraction Kit (Qiagen), following the manufacturer's instructions. Partial sequences of the mitochondrial genes 16SrRNA and Cytochrome $b$ (Cytb) and the nuclear genes recombination activating gene 1 (Rag1), recombination activating gene 2 (Rag2) and myosin, heavy chain 6 , cardiac muscle, alpha (Myh6) were amplified by polymerase chain reaction (PCR) with the same primers utilized by Oliveira et al. [1]. Amplifications were performed in a total volume of $25 \mu$ l consisting of 2.5 $\mu \mathrm{l}$ of $10 \mathrm{X}$ buffer $(10 \mathrm{mM}$ Tris-HCL $+15 \mathrm{mM} \mathrm{MgCl} 2$ buffer), $0.5 \mu \mathrm{l}$ of $\mathrm{MgCl}_{2}(50 \mathrm{mM}), 0.5 \mu \mathrm{l}$ of each primer (5 $\mu \mathrm{M}) ; 0.4 \mu \mathrm{l}$ of dNTPs (200 nM of each), $0.2 \mu \mathrm{l}$ of Taq Platinum polymerase (Invitrogen; $5 \mathrm{U} / \mu \mathrm{l}), 1 \mu \mathrm{l}$ of template DNA (10-50 ng) and 19.4 $\mu \mathrm{l}$ of $\mathrm{dd}_{2} \mathrm{O}$. The thermo-cycler profile used for the fragments 16SrRNA and Cyt $b$ consisted of 35 cycles, $30 \mathrm{~s}$ at $95^{\circ} \mathrm{C}, 45-120 \mathrm{~s}$ at $50-55^{\circ} \mathrm{C}$ (according to primer and species), and $90 \mathrm{~s}$ at $72^{\circ} \mathrm{C}$. Nested-PCR was used to amplify the nuclear genes Rag1, Rag2 and Myh6. Amplification conditions for these genes in both rounds of PCR consisted of 15 cycles, $30 \mathrm{~s}$ at $95^{\circ} \mathrm{C}$, $45 \mathrm{~s}$ at $56^{\circ} \mathrm{C}$ (according to primer), and $30 \mathrm{~s}$ at $72^{\circ} \mathrm{C}$ followed by 15 cycles, $30 \mathrm{~s}$ at $95^{\circ} \mathrm{C}, 45 \mathrm{~s}$ at $54^{\circ} \mathrm{C}$ (according to primer), and $90 \mathrm{~s}$ at $72^{\circ} \mathrm{C}$. PCR products were purified using ExoSap-IT ${ }^{\oplus}$ (USB Corporation), sequenced using the "Big DyeTM Terminator v 3.1 Cycle Sequencing Ready Reaction Kit" (Applied Biosystems), purified again by ethanol precipitation and loaded into an automatic sequencer 3130-Genetic Analyzer (Applied Biosystems) at Instituto de Biociências, Universidade Estadual Paulista, Botucatu, São Paulo, Brazil. Contigs were assembled and edited in BioEdit 7.0.9.0 [22]. In cases of unclear nucleotide identity, 
Table 1 Species of Bryconidae analyzed in the present phylogenetic study

\begin{tabular}{|c|c|c|c|c|c|}
\hline Species & Voucher & Specimen & Locality & Geographic position & Position in Figure 1 \\
\hline \multirow{2}{*}{ Brycon amazonicus } & \multirow{2}{*}{2187} & 15565 & \multirow{2}{*}{ Laguna de Castilleros, Venezuela } & \multirow{2}{*}{ 07030'50.9"N 6609'19.8" W } & \multirow{2}{*}{4} \\
\hline & & 15567 & & & \\
\hline Brycon amazonicus & 2859 & 18988 & Rio Tomo, Colombia & $04^{\circ} 25^{\prime} 27.1^{\prime \prime} \mathrm{N} 69^{\circ} 17^{\prime} 12.5^{\prime \prime} \mathrm{W}$ & 5 \\
\hline Brycon amazonicus & 834 & 8835 & Rio Negro, Amazonas, Brazil & $03^{\circ} 05^{\prime} 05.2^{\prime \prime} .559^{\circ} 47^{\prime} 23.7^{\prime \prime} \mathrm{W}$ & 10 \\
\hline Brycon aff. atrocaudatus & 1356 & 17096 & Rio Santa, Peru & $08^{\circ} 40^{\prime} 24.0^{\prime \prime}$ S 780.'16.3" W & 13 \\
\hline Brycon chagrensis & 2749 & 18510 & Río Llano Sucio, Panama & $09^{\circ} 19^{\prime} 26.2^{\prime \prime}$ N 7946'08.2" W & 2 \\
\hline Brycon falcatus & 2668 & 15563 & Laguna de Castilleros, Venezuela & $07030^{\prime} 50.9^{\prime \prime}$ N 6609'19.8" W & 4 \\
\hline Brycon falcatus & 5146 & 26278 & Rio Machado, Rondônia, Brazil & $10^{\circ} 43^{\prime} 36.0^{\prime}$ S $61^{\circ} 55^{\prime} 12.9^{\prime \prime} \mathrm{W}$ & 14 \\
\hline Brycon falcatus & 6878 & 32395 & Rio Negro, Amazonas, Brazil & $00^{\circ} 08^{\prime} 09.4^{\prime \prime}$ S $67^{\circ} 05^{\prime} 03.4^{\prime \prime} \mathrm{W}$ & 6 \\
\hline Brycon cf. falcatus & 8109 & $\begin{array}{l}37580 \\
37581\end{array}$ & Rio Culuene, Mato Grosso, Brazil & $13^{\circ} 49^{\prime} 00.0^{\prime \prime} \mathrm{N} 53^{\circ} 15^{\prime} 08.0^{\prime \prime} \mathrm{W}$ & 16 \\
\hline Brycon ferox & 2855 & 18979 & Aquaculture & - & - \\
\hline Brycon ferox & 8099 & 37528 & Rio Mucuri, Minas Gerais, Brazil & $17^{\circ} 41^{\prime} 42.4^{\prime} \mathrm{S} 40^{\circ} 46^{\prime} 11.3^{\prime \prime} \mathrm{W}$ & 23 \\
\hline Brycon ferox & 8100 & 37529 & Rio Mucuri, Minas Gerais, Brazil & $17^{\circ} 41^{\prime} 42.4^{\prime} \mathrm{S} 40^{\circ} 46^{\prime} 11.3^{\prime \prime} \mathrm{W}$ & 23 \\
\hline Brycon gouldingi & 3130 & 19203 & Lagoa da Égua, Mato Grosso, Brazil & $13^{\circ} 20^{\prime} 05.1^{\prime \prime}$ S $50^{\circ} 42^{\prime} 16.2^{\prime \prime} W$ & 15 \\
\hline Brycon henni & 2857 & 18984 & Colombia & Aquaculture & - \\
\hline Brycon hilarii & 3805 & 21895 & Rio Negro, Mato Grosso do Sul, Brazil & $19^{\circ} 34^{\prime} 33.7^{\prime}$ S $56^{\circ} 14^{\prime} 49.5^{\prime \prime} W$ & 21 \\
\hline Brycon hilarii & 2766 & 17634 & Rio Cuiabá, Rio São Lourenço, Mato Grosso, Brazil & $17^{\circ} 50^{\prime} 45.3^{\prime \prime}$ S $57^{\circ} 24^{\prime} 11.7^{\prime \prime} \mathrm{W}$ & 20 \\
\hline Brycon hilarii & 4676 & 24810 & Rio Cuiabá, Mato Grosso, Brazil & $15^{\circ} 54^{\prime} 50.0^{\prime} \mathrm{S} 56^{\circ} 02^{\prime} 07.0^{\prime} \mathrm{W}$ & 17 \\
\hline Brycon insignis & 2309 & 16075 & Lagoa Feia, Rio de Janeiro, Brazil & $22^{\circ} 00^{\prime} 00.0^{\prime \prime} \mathrm{S} 41^{\circ} 20^{\prime} 00.0^{\prime \prime} \mathrm{W}$ & 24 \\
\hline Brycon melanopterus & 9778 & 38096 & Rio Amazonas, lquitos, Peru & $03^{\circ} 48^{\prime} 11.5^{\prime} \mathrm{S} 73^{\circ} 13^{\prime} 12.4^{\prime \prime} \mathrm{W}$ & 11 \\
\hline Brycon moorei & 2858 & 18986 & Rio Rancheria, Colombia & $11^{\circ} 0^{\prime} 23.57$ N $74^{\circ} 14^{\prime} 48.80^{\prime \prime} \mathrm{W}$ & 1 \\
\hline Brycon moorei & 12817 & 55010 & Rio Cauca, Antioquia, Colombia & 0757'28.5" N 75¹2'00.0" W & 3 \\
\hline Brycon nattereri & 2856 & $\begin{array}{l}18981 \\
18982\end{array}$ & Rio Paraná, São Paulo, Brazil & $20^{\circ} 55^{\prime} 27.90^{\prime \prime} \mathrm{S} 51^{\circ} 37^{\prime} 32.62^{\prime \prime} \mathrm{W}$ & 30 \\
\hline Brycon nattereri & 8101 & 37541 & Rio Capivari, Minas Gerais, Brazil & $21^{\circ} 30^{\prime} 16.0^{\prime \prime} \mathrm{S} 44^{\circ} 34^{\prime} 29^{\prime \prime} \mathrm{W}$ & 25 \\
\hline Brycon opalinus & 6303 & 29001 & Rio Itagaçaba, São Paulo, Brazil & $22^{\circ} 39^{\prime} 26.3^{\prime \prime}$ S $44^{\circ} 45^{\prime} 49.8^{\prime \prime} W$ & 26 \\
\hline Brycon opalinus & 6306 & 29349 & Rio dos Prazeres, São Paulo, Brazil & 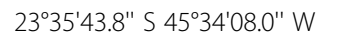 & 27 \\
\hline Brycon orbignyanus & 2746 & 18004 & Aquaculture, Brazil & $21^{\circ} 59^{\prime} 45.74^{\prime \prime} \mathrm{S} 47^{\circ} 25^{\prime} 36.57^{\prime} \mathrm{W}^{\prime}$ & 28 \\
\hline Brycon orthotaenia & 249 & 4215 & Rio São Francisco, Minas Gerais, Brazil & $18^{\circ} 11^{\prime} 28.50^{\prime \prime} \mathrm{S} 45^{\circ} 14^{\prime} 51.42^{\prime \prime} \mathrm{W}$ & 22 \\
\hline Brycon pesu & 8111 & $\begin{array}{l}37578 \\
37579\end{array}$ & Rio das Garças, Mato Grosso, Brazil & $15^{\circ} 54^{\prime} 18.1^{\prime \prime}$ S $52^{\circ} 19^{\prime} 24.2^{\prime \prime} \mathrm{W}$ & 18 \\
\hline Brycon pesu & 5320 & 26930 & Rio Jari, Amapá, Brazil & $00^{\circ} 34^{\prime} 11^{\prime \prime} \mathrm{S} 52^{\circ} 33^{\prime} 19^{\prime \prime} \mathrm{W}$ & 7 \\
\hline Brycon pesu & 9409 & 42567 & Rio Guamá, Pará, Brazil & $01^{\circ} 34^{\prime} 00.5^{\prime \prime}$ S $47^{\circ} 09^{\prime} 51.4^{\prime \prime} \mathrm{W}$ & 8 \\
\hline Brycon petrosus & 2750 & 18504 & Río Llano Sucio, Panama & $09^{\circ} 19^{\prime} 26.2^{\prime \prime}$ N 7946'08.2" W & 2 \\
\hline Brycon vermelha & 9066 & 42508 & Rio Mucuri, Minas Gerais, Brazil & $17^{\circ} 41^{\prime} 42.4^{\prime} \mathrm{S} 40^{\circ} 46^{\prime} 11.3^{\prime \prime} \mathrm{W}$ & 23 \\
\hline Brycon sp. & 5837 & 28350 & Estação de Piscicultura da CEMIG, Minas Gerais, Brazil & $15^{\circ} 31^{\prime} 19.0^{\prime \prime} \mathrm{S} 41^{\circ} 30^{\prime} 18.0^{\prime \prime} \mathrm{W}$ & 19 \\
\hline \multirow[t]{2}{*}{ Chilobrycon deuterodon } & 9334 & 45001 & Rio Tumbes, Peru & $03^{\circ} 48^{\prime} 17.9^{\prime \prime} \mathrm{S} 80^{\circ} 29^{\prime} 52.5^{\prime \prime} \mathrm{W}$ & 12 \\
\hline & & 45002 & & & \\
\hline Henochilus wheatlandii & 1221 & 25846 & Rio Santo Antônio, Minas Gerais, Brazil & $17^{\circ} 5360.00^{\prime \prime} \mathrm{S} 40^{\circ} 13^{\prime} 0.00^{\prime \prime} \mathrm{W}$ & 23 \\
\hline Salminus affinis & 12817 & 55009 & Rio Cauca, Antioquia, Colombia & $07^{\circ} 57^{\prime} 28.5^{\prime \prime} \mathrm{N} 75^{\circ} 12^{\prime} 00.0^{\prime \prime} \mathrm{W}$ & 3 \\
\hline Salminus brasiliensis & 850 & 9025 & Rio Mogi-Guaçu, São Paulo, Brazil & $21^{\circ} 55^{\prime} 37.60^{\prime \prime} S 47^{\circ} 22^{\prime} 4.40^{\prime \prime} \mathrm{W}$ & 28 \\
\hline
\end{tabular}


Table 1 Species of Bryconidae analyzed in the present phylogenetic study (Continued)

\begin{tabular}{|c|c|c|c|c|c|}
\hline Salminus franciscanus & 8090 & 37503 & Rio São Francisco, Minas Gerais, Brazil & $18^{\circ} 11^{\prime} 21.0^{\prime} \mathrm{S} 45^{\circ} 15^{\prime} 10.3^{\prime \prime} \mathrm{W}$ & 22 \\
\hline Salminus hilarii & 84 & 7615 & Rio Paranapanema, São Paulo, Brazil & $23^{\circ} 20^{\prime} \mathrm{S} 48^{\circ} 34^{\prime} \mathrm{W}$ & 29 \\
\hline Salminus sp. & 8160 & 38065 & Rio Tapirapé, Pará, Brazil & $05^{\circ} 22^{\prime} 22.30^{\prime \prime} \mathrm{S} 49^{\circ} 07^{\prime} 0.94^{\prime \prime} \mathrm{W}$ & 9 \\
\hline
\end{tabular}

Asterisks indicate specimens sequenced in Oliveira et al. [1].

IUPAC ambiguity codes were applied. All obtained sequences were deposited in GenBank (Table 1).

\section{Alignment and phylogenetic analyses}

Sequences of each gene were aligned using the Muscle algorithm under default parameters [23] and the alignments inspected by eye for any obvious misalignments that were subsequently corrected. A quality control step was included in our workflow as described in Oliveira et al. [1]. Genetic distances among sequences were calculated in Mega 5.04 [24]. To evaluate the occurrence of substitution saturation, we estimated the index of substitution saturation (Iss) in DAMBE 5.2.31 [25] as described in Xia et al. [26] and Xia and Lemey [27].

A set of six reasonable partitioning schemes, ranging from 1 to 13 partitions (Table 2), was tested following

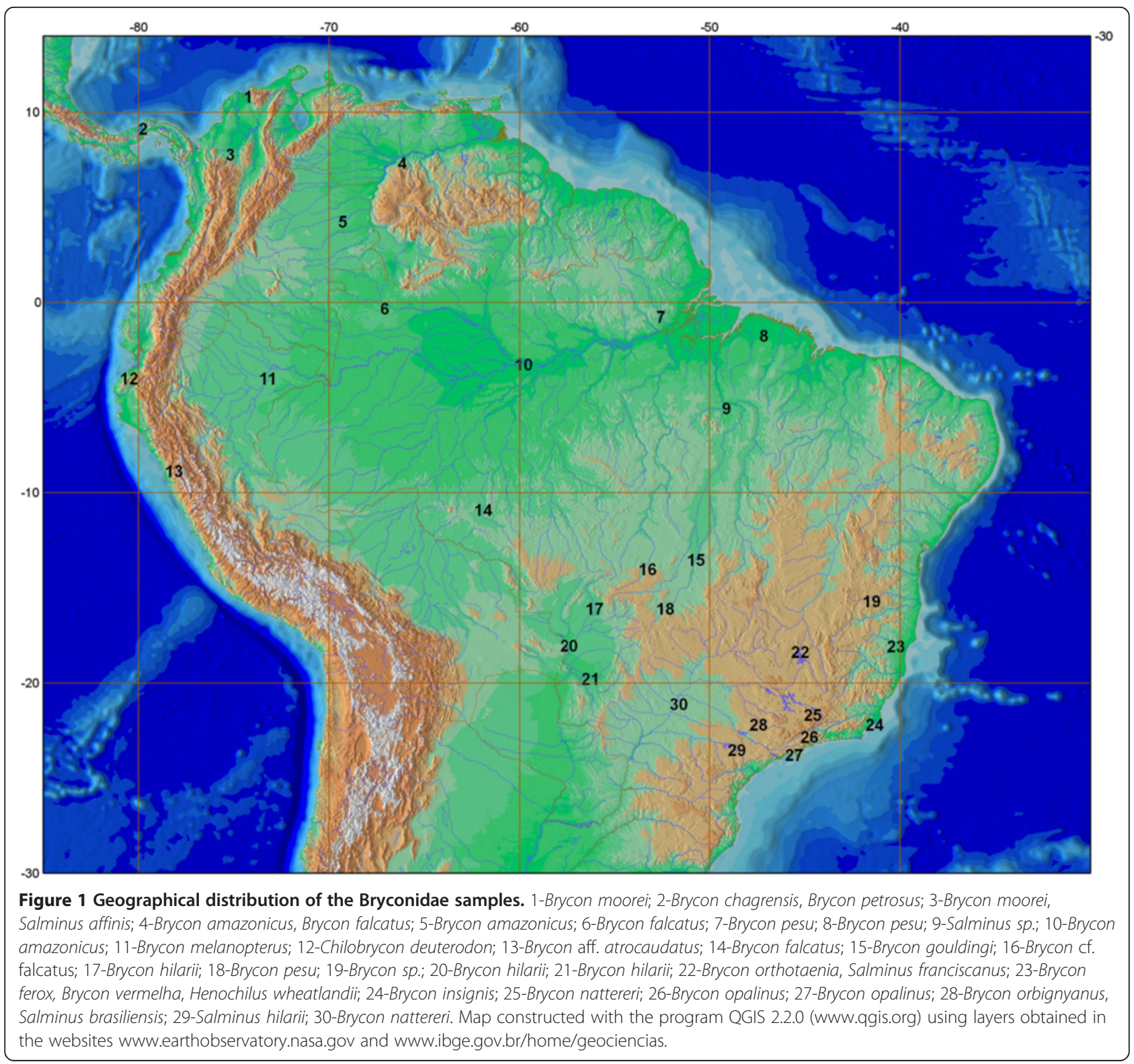


Table 2 Comparison of log likelihoods, AIC and BIC values among different partitioning schemes (from 1 to 13 partitions)

\begin{tabular}{cccccc}
\hline Number of partitions* & Number of parameters & $\mathbf{L}_{\boldsymbol{M L}}$ & AIC & Delta $_{\boldsymbol{i}}$ & BIC $_{\boldsymbol{M L}}$ \\
\hline 1 & 9 & 181065.424 & 362148.847 & 9956.687 & 362163.896 \\
2 & 19 & 179598.394 & 359234.787 & 7042.627 & 359266.555 \\
$4 \mathrm{~A}$ & 39 & 180039.825 & 360157.651 & 7965.491 & 360222.859 \\
$4 \mathrm{~B}$ & 39 & 179526.116 & 359130.233 & 6938.073 & 359195.441 \\
5 & 49 & 179380.393 & 358858.787 & 6666.627 & 358940.715 \\
13 & 129 & 175967.080 & 352192.160 & 0.000 & 352407.849
\end{tabular}

*1 partition = all datasets; 2 partitions = mitochondrial (16S + CytB) and nuclear (Myh6 + Rag1 + Rag2); 4 partitions A = 16S and 1st, 2nd, and 3rd codon position of protein coding genes; 4 partitions $B=16 \mathrm{~S}+\mathrm{CytB}$ and 1st, 2 nd, and 3rd codon position of nuclear genes; 5 partitions = by each gene $(16 \mathrm{~S}+\mathrm{Cyt} B+\mathrm{Myh} 6+\mathrm{Rag} 1+$ Rag2); 13 partitions $=16 \mathrm{~S}+$ each codon position of each protein coding genes (1st, 2nd, and 3rd codon position of CytB; 1st, 2nd, and 3rd codon position of Myh6; 1st, 2nd, and 3rd codon position of Rag1; 1st, 2nd, and 3rd codon position of Rag2).

For each type of analysis, the following results are shown: total number of parameters, log likelihood calculated using RAxML $\left(L_{M L}\right)$, $A I C$ values, the difference in $\mathrm{AIC}$ values among model $i$ and the best model $(\Delta i=\mathrm{AIC} i-\mathrm{AICmin}), \mathrm{BIC}_{M L}$ values.

the procedures outlined by Li et al. [28] using the AIC and BIC. The best-fit model of nucleotide substitution was searched in Mega 5.04 [24] under default parameters using the Akaike information criterion (see [29], for justification).

Maximum parsimony (MP) analyses were conducted with PAUP* 4.0b10 [30]. Heuristic searches were performed with minimally 1000 random addition replicates and TBR branch swapping. All characters were unordered, all character transformations were equally weighted, and branches with a maximum length of zero were collapsed. Gaps were treated as missing data since experiments were they were treated as a fifth base did not result in better resolved trees. Clade robustness was assessed using 1000 bootstrap pseudoreplicates [31] with the same parameters as described above.

RAxML [32], running in the web servers RAxMLHPC2 on TG $[33,34]$, was used for all maximum likelihood analyses with a mixed partition model. Random starting trees were ran for each independent ML tree search, and all other parameters were set to default values. All ML analyses were conducted following the 13 partitions sch. as suggested by the AIC and BIC (Table 2). Topological robustness was investigated using 1000 nonparametric bootstrap replicates.

Phylogenetic analyses using a partitioned Bayesian inference were conducted in MrBayes 3.1.2 [35]. A mixed model analysis was implemented, allowing individual models of nucleotide substitution to be estimated independently for each partition. Because MrBayes 3.1.2 only implements 1, 2, and 6 substitution rate models, it was often not possible to implement the preferred model as selected by the AIC. In these situations, the nearest overparameterized model was used to avoid the negative consequences of model violation or underparameterization [28,36]. As a consequence, the model for all partitions was set as "lset nst $=6$ " and "rates = invgamma" $(G+I)$, with the commands "unlink" and "prset ratepr $=$ variable" used to unlink the model parameters across the data partitions and define a rate multiplier for each partition. Two independent Bayesian analyses were conducted. Four independent MCMC chains were run with 30,000,000 replicates each, with one tree sampled every 1000 steps. The distribution of the log likelihood scores was examined to determine stationarity for each search and decide if extra runs were required to achieve convergence using the program Tracer 1.4 [37]. Initial trees estimated prior to convergence were discarded as part of the burn-in procedure, and the remaining trees were used to construct a $50 \%$ majority rule consensus tree in PAUP\%.

The estimation of divergence times in the inferred phylogeny was carried out using BEAST (Bayesian evolutionary analysis sampling trees) 1.8.0 [38] on a reduced dataset that included the family Bryconidae and representatives of the families Gasteropelecidae and Triportheidae. To calibrate our molecular tree we followed the guideline proposed by Parham et al. [39]. Initially, two fossils were chosen: Lignobrycon ligniticus and Brycon avus. Lignobrycon ligniticus (Woodward, 1898) (type specimen: BMNH P9012) was described in the genus Tetragonopterus and moved to Lignobrycon by Eigenmann and Myers [40]. Malabarba [41] in a phylogenetic study showed that L. ligniticus is the sister group of $L$. myersi (a species included in our phylogeny) and these two species are the sister group of Triportheus. Brycon avus (Woodward, 1898) (type specimen: BMNH P9224) was described in the genus Tetragonopterus and moved to Brycon by Travassos and Silva [42]. Malabarba ([43] - unpublished thesis) showed that B. avus is placed within the genus Brycon but its relationships with the remaining species of this genus was not resolved which make very difficult its use in our phylogeny. Considering that B. avus does not meet all criteria proposed by Parham et al. [39] we discuss it putative relationship with the species we analyzed in the present study but we did not use it to calibrate our trees. 
These two species were described based on complete specimens collected in the Tremembé Formation, Taubaté Basin, São Paulo, Brazil. Geological studies [44] have confirmed the age of this formation as Oligocene, as also suggested by studies in mammalian fossils [45] and pollens $[46,47]$. According to the International Commission on Stratigraphy (www.stratigraphy.org) Oligocene extended from 33.9 to 23.03 million years ago (Ma). These dates were implemented in BEAST with a log-normal prior offset with a mean and standard deviation of $28.5 \pm 5.5$. We used a birth-death model for the speciation likelihood and a random starting tree. The analysis was run for 50 million generations and sampled every $10000^{\text {th }}$ generation. Stationarity and sufficient mixing of parameters (ESS > 200) were checked using Tracer 1.5 [47]. A consensus tree was built using TreeAnnotator v 1.6.2 [48].

\section{Results}

Partial sequences of two mitochondrial (16SrRNA and Cytb) and three nuclear genes (Myh6, Rag1 and Rag2) were obtained for 254 specimens, 41 of which were sequenced in the present study (Additional file 1). The final matrix contained 4699 bp and was deposited in TreeBase (www.treebase.org) under number 15409 and in DRYAD (www.datadryad.org - http://datadryad.org/ resource/doi:10.5061/dryad.kt24p).

Missing data due to problems with the PCR, sequencing problems, or missing data in GenBank corresponded to $11.4 \%$ of the matrix (Table 3). Data absence was more prevalent among nuclear (15.7\%) than mitochondrial genes (4.9\%), perhaps due to non-conserved priming regions and a higher risk of cross-contamination in the nested PCR procedure. For each matrix and gene, the number and percentage of sequences obtained, their size (bp), the number of variable sites, their base pair composition, the overall mean genetic distance (p-distance), the best substitution model for the gene, the $\alpha$ (shape) parameter of $\Gamma$ distribution, the proportion of invariant (I) sites, the number of informative characters under parsimony, and the proportion of informative characters under parsimony are presented in Table 3. Under the MP criterion, $53.2 \%$ of the positions were phylogenetically informative. The overall mean genetic distance observed was between $0.083 \pm 0.004$ (Myh6) and $0.216 \pm$ 0.007 (CytB), suggesting that the analyzed sequences contain sufficient genetic variation for an informative phylogenetic study of species, genera and families. Each gene and codon position partition was further tested to investigate the occurrence of substitution saturation [26,27]. The results showed significant saturation for only the 3rd codon position of Cytb in the symmetrical topology test (results not shown); however, considering that the Iss.c value is greater than the Iss value and that there is no significant saturation in the asymmetrical topology test, the information found at this position can be used in the phylogenetic analysis $[26,27]$. The best-fitting model of nucleotide substitution calculated for each gene was: GTR $+\mathrm{I}+\Gamma(16 \mathrm{~S})$, TN93 + I + (CytB), T92 + I + Г (Myh6) and K2P + I + Г (Rag1, Rag2) (Table 3$)$. The combined data set contains significant phylogenetic information, as most major lineages along the backbone of the tree were supported by high bootstrap values.

Six different partitioning schemes, ranging from one to 13 partitions (Table 2), were tested to establish the optimal number of data partitions (following [49]) for the final analysis. The results showed that the 13 partition model was the best choice; however, ML analysis conducted with the other partitioning schemes produced the same final topology, with minor differences in branch length and support values (data not shown).

Table 3 Information content and characteristics of each gene partition

\begin{tabular}{|c|c|c|c|c|c|c|}
\hline & \multicolumn{5}{|c|}{ Gene } & \multirow[b]{2}{*}{ Total } \\
\hline & $16 S$ & CytB & Myh6 & Rag1 & Rag2 & \\
\hline Number of sequences & $254(100 \%)$ & $229(90.2 \%)$ & $215(84.6 \%)$ & $207(81.5 \%)$ & $220(86.6 \%)$ & 254 \\
\hline bp after alignment & 653 & 992 & 755 & 1265 & 1034 & 4699 \\
\hline Number of variable sites & 393 & 684 & 392 & 874 & 685 & 3028 \\
\hline Number of informative characters under parsimony & 326 & 585 & 327 & 680 & 581 & 2499 \\
\hline$\%$ informative characters under parsimony & 49.9 & 58.9 & 43.3 & 51.4 & 56.2 & 53.2 \\
\hline$\Pi_{\mathrm{T}}$ & 0.227 & 0.296 & 0.246 & 0.226 & 0.231 & 0.245 \\
\hline$\Pi_{C}$ & 0.236 & 0.293 & 0.214 & 0.240 & 0.252 & 0.249 \\
\hline$\Pi_{\mathrm{A}}$ & 0.313 & 0.265 & 0.307 & 0.252 & 0.245 & 0.271 \\
\hline$\Pi_{\mathrm{G}}$ & 0.224 & 0.146 & 0.234 & 0.283 & 0.272 & 0.234 \\
\hline Overall mean genetic distance ( $\mathrm{p}$-distance) & $0.122 \pm 0.008$ & $0.216 \pm 0.007$ & $0.083 \pm 0.004$ & $0.108 \pm 0.004$ & $0.110 \pm 0.004$ & $0.134 \pm 0.002$ \\
\hline Nucleotide substitution model & $\mathrm{GTR}+1+\Gamma$ & TN93 + I+ & $\mathrm{T} 92+I+\Gamma$ & $\mathrm{K} 2 \mathrm{P}+\mathrm{I}+\Gamma$ & $\mathrm{K} 2 \mathrm{P}+\mathrm{I}+\Gamma$ & $\mathrm{GTR}+1+\Gamma$ \\
\hline a (shape) parameter of $\Gamma$ distribution & 0.65 & 0.65 & 1.03 & 0.89 & 0.97 & 0.61 \\
\hline Proportion of invariants (I) sites & 0.32 & 0.29 & 0.42 & 0.22 & 0.26 & 0.29 \\
\hline
\end{tabular}


Throughout the text and in the figures, measures of support are represented by a series of three numbers on selected internal branches of the trees subtending labeled clades, with the first number indicating the posterior probabilities from the Bayesian analysis (B) and the following numbers indicating the non-parametric bootstrap percentages from the ML and MP analyses, respectively (e.g., 1/100/100; see Figure 2). Dashes represent values lower than 0.5 (B) or 50\% (ML, MP), and asterisks represent nodes with varying topologies depending on the analytical method employed. Nodes without support values greater than $0.5(\mathrm{~B})$ and $50 \%(\mathrm{ML}, \mathrm{MP})$ were collapsed. A ML tree summarizing the phylogenetic results is presented in Figure 2. The same tree expanded to show all taxa is presented in the Additional file 2. The general tree topology observed in all analyses was very similar, although statistical support was weak at some nodes. Thus, we choose the Bayesian topology obtained with BEAST to discuss the relationships among taxa and we present the differences among this result and

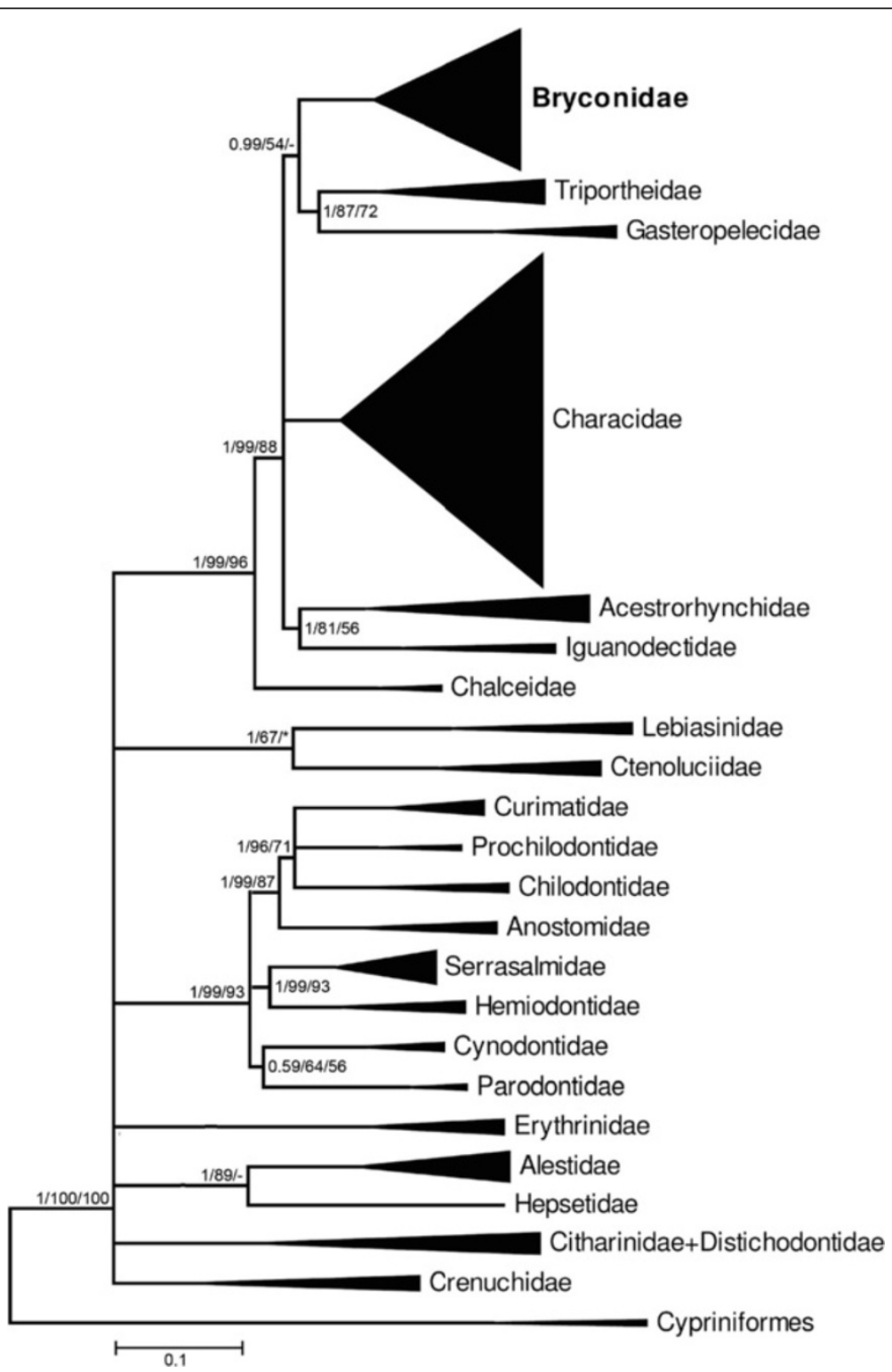

Figure 2 Summary tree showing relationships among major lineages obtained by a maximum likelihood (ML) partitioned analysis of the concatenated dataset and emphasizing the relationships among species of Bryconidae (bold). A series of three numbers (e.g., 1/100/ 87) at each of the main nodes represents the posterior probability for that split obtained in the Bayesian analysis (B), percentage of bootstrap support obtained by ML analysis, and percentage of bootstrap support obtained by MP analysis, respectively (1000 bootstrap replicates). Dashes represent values less than 0.5 (B) or 50\% (ML, MP). Asterisks represent nodes that were not obtained by B or MP analyses. 
those obtained with other techniques in the text where appropriated.

\section{Phylogenetic relationships of the Bryconidae}

As shown in Figure 3, Bryconidae is monophyletic with very strong statistical support (1/100/100). Bryconidae appears as the sister group of the Gasteropelecidae + Triportheidae in all analyses but the support in MP studies was less than 50\% (0.99/54/-) (Figure 2). Within the Bryconidae, we identified five clades and the genus Brycon turned out as polyphyletic (Figure 3). The first clade $(1 / 100 / 100)$ is composed of some trans-Andean species of Brycon and Chilobrycon. The second clade $(1 / 100 / 100)$ is composed entirely of Salminus. The third clade (1/100/100) is comprised of four samples of Brycon pesu. The fourth clade $(1 / 89 / 100)$ is composed of one trans-Andean species of Brycon and additional Brycon species from the Amazon, Orinoco, São Francisco, and Paraná-Paraguay basins. The fifth clade (1/99/100) is composed of some Brycon from the Amazon and Paraná basins, Brycon from the Brazilian coast and Henochilus.

\section{Estimates of divergence times of Bryconidae clades}

Using the fossil of Lignobrycon ligniticus to calibrate our phylogenetic tree we found that the mean substitution rate for the Bryconidae dataset, estimated using BEAST, was $0.001847 \%$ per Ma. The origin of the Bryconidae, calculated according the available fossil information described above, was estimated at $46.7 \mathrm{Ma}$ (95\% HPD: 34.9 - 58.9) (Figure 4). Within the Bryconidae, clade 1 originated 35.7 Ma (95\% HPD: 26.1 - 45.1), clade 2 originated $29.6 \mathrm{Ma}$ (95\% HPD: 21.8 - 37.2), clade 3 originated $26.7 \mathrm{Ma}$ (95\% HPD: $20.1-34.2$ ) and clades 4 and 5 both originated 22.3 Ma (95\% HPD: 16.3 - 28.1).

\section{Discussion}

\section{Phylogenetic relationships among the Bryconidae and} other Characiformes taxa

Our study represents the first phylogenetic analysis in which all genera currently assigned to the Bryconidae $[1,4]$ were investigated. Our results indicate that Brycon, Chilobrycon and Henochilus belong to a monophyletic group, as suggested by Lima [4]. Our study also corroborates the hypothesis that Salminus is closely related to Brycon [1,17,20,21,50,51].

All of our analyses identified the Bryconidae as the sister group of the clade composed of the families Gasteropelecidae and Triportheidae This is an interesting result, as our previous study [1] suggested that the Bryconidae may be the sister group of the Gasteropelecidae. These different results appear to be due to the larger number of representatives of the Bryconidae in the present analysis, emphasizing the importance of using a large number of taxa in phylogenetic studies.
According to Weitzman [52], the presence of expanded coracoids in Triportheus and the so-called subfamily Gasteropelecinae is likely due to convergent evolution; i.e., they arose independently in these groups. This view was adopted by several other authors, such as Castro and Vari [53] and Mirande [18]. Thus, our results are inconsistent with the current morphology-based topology that identifies the Triportheidae and the Gasteropelecidae as non-sister groups. However, based on morphological analyses, Gregory and Conrad [54] suggested that "Chalcinus (=Triportheus) is much the nearer to the structural ancestor of Gasteropelecus", a hypotheses similar to that found in the present study. In contrast, the putative relationship between Triportheus and the Bryconidae, is supported by several authors, including Malabarba [41] and Mirande [18]. However, considering that the support in MP studies was lower than $50 \%$ further studies involving more samples and more genes will be necessary for a better discussion about the relationships of these families.

\section{Phylogenetic position of Salminus}

Salminus is an economically and ecologically important genus, composed of medium to large fishes. Members of the genus are found throughout most of South America, including one trans-Andean representative, S. affinis. The taxonomic history of Salminus is complex. In the first review of the genus, Eigenmann [55] recognized S. affinis (Magdalena River and Upper Amazonas), S. hilarii (Paraná, São Francisco, Amazon and Orinoco Rivers), S. maxillosus (La Plata basin), and S. brevidens (São Francisco River). Presently, four species are recognized: S. affinis (transAndean species from Magdalena, Rancheria and Sinú Rivers, Colombia), S. hilarii (São Francisco, Upper Paraná river basins, Araguaia, Tocantins, Upper Amazonas and Orinoco Rivers), S. brasiliensis (La Plata Basin, Jacuí River and Upper Madeira river basin), and Salminus franciscanus [56-59]. A morphological distinction among specimens of S. hilarii from São Francisco and Upper Paraná river basins and those from Araguaia, Tocantins, Upper Amazonas and Orinoco Rivers was observed by Lima [57] and thus in the present study the first group is here identified as S. hilarii and the second as Salminus sp.

Morphological studies do not suggest a close relationship between Salminus and Brycon [4,16,18,57]. Géry [15], without a phylogenetic analyses, included the tribe Salminini in the subfamily Bryconinae. Our study corroborates previous molecular hypothesis that identify Salminus as closely related to Brycon $[1,20,21,51,60]$. Moreover, our results show that Salminus is a genus interspersed among Brycon species, as observed by Calcagnotto et al. [20].

Our phylogeny is the first published hypothesis of the evolutionary history of this genus and shows that Salminus hilarii is the sister group of all remaining species and that 


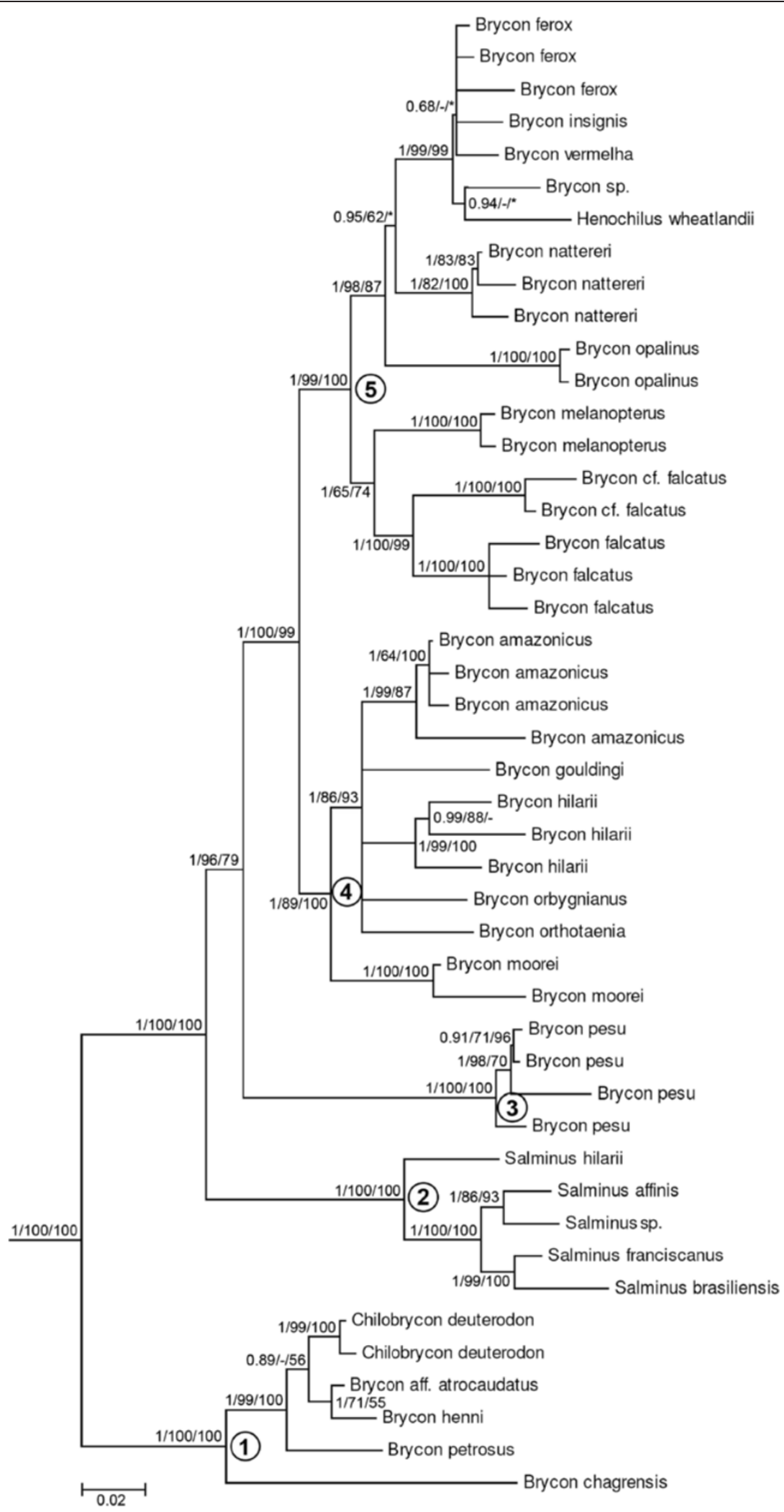

Figure 3 Best maximum likelihood (ML) tree of the Bryconidae obtained in the partitioned analysis of the concatenated dataset. Numbered nodes as referenced in text and values shown in Figure 2. Numbers after species names, between braches, refer to collecting sites shown in the Figure 1; dashes represent fishes from aquaculture without known locality. 


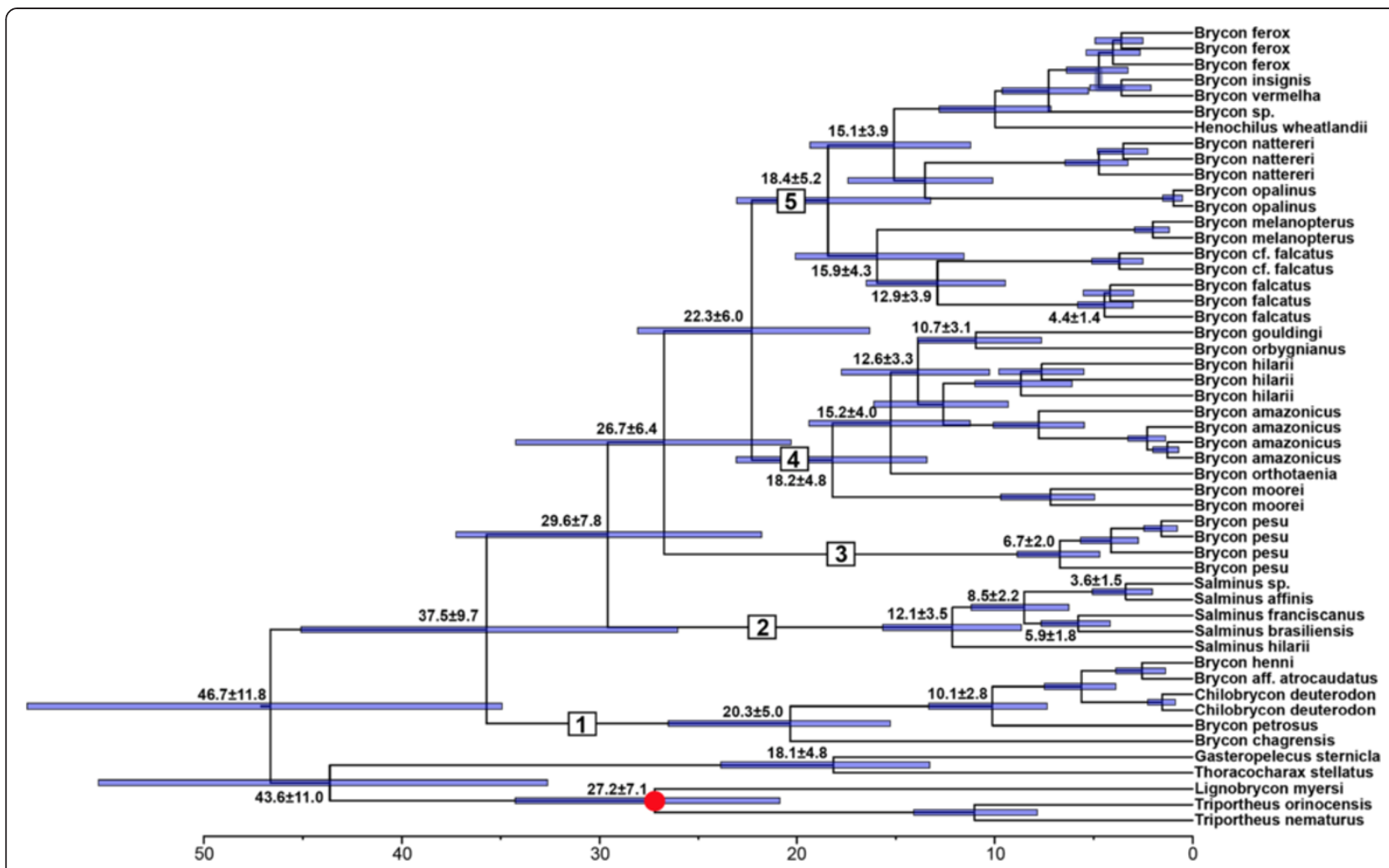

Figure 4 The BEAST chronogram tree from $\mathbf{5 0}$ million generations, indicating the divergence over time of the family Bryconidae.

Red circle shows the calibration points based on the fossil Lignobrycon ligniticus ( $28.5 \pm 5.5 \mathrm{Ma}$ ). Scale = millions of years before present.

Salminus sp. and S. affinis and S. brasiliensis and S. franciscanus are sister species. However, Lima [57] reported similar results in his unpublished thesis.

\section{Phylogenetic relationships among Bryconidae species}

According to our results, the family Bryconidae consists of five main clades. The first clade is composed of four trans-Andean species of Brycon and Chilobrycon. $B$. chagrensis is the sister group of all remained species in this clade. After this we have B. petrosus in the BEAST analysis and B. henni in the ML analysis as a sister group to a monophyletic lineage with two clades, one composed of $B$. aff. atrocaudatus and B. henni (B. petrosus) and the second consisting of $C$. deuterodon. In their description of the genus Chilobrycon, Géry and Rham [61] suggested that this genus belongs to the subfamily Bryconinae and can be differentiated from Brycon species primarily by the presence of spatulated and tricuspid teeth and the absence of an upper lip. Although several trans-Andean species of Brycon were not available for analysis in the present study, the species $B$. chagrensis was described by Kner (1863) as Chalcinopsis chagrensis that was considered a junior synonymous of $B$. chagrensis [4] and thus the whole taxonomy of this group need to be revised.
The second clade is composed of all the species of Salminus, as discussed above. The third clade consists of four samples of Brycon pesu. Eigenmann [62] proposed that the genus Holobrycon include Brycon pesu Müller \& Troschell, 1841, because adult specimens of this genus lack a fontanel, unlike that observed in all Brycon species. Thus, our data reinforce Eigenmann's proposition that Holobrycon represents a valid genus; however, these nomenclature changes require close evaluation in future studies.

The fourth clade is comprised of one trans-Andean species of Brycon (B. moorei) and several Brycon species from the Amazon, Orinoco, São Francisco, and Paraná-Paraguay Rivers. The inclusion of $B$. moorei in this clade and the presence of Brycon species in our first clade show that the cis- and trans-Andean Brycon spp. are not monophyletic. The relationship among cis-Andean species of this clade was not resolved in the present study. Notably, the species B. orthotaenia, B. orbignyianus and B. hilarii are morphologically very similar (FCT Lima, pers. comm.).

The fifth clade is composed of two lineages: the first contains B. melanopterus, B. falcatus, and B. cf. falcatus (Amazon and Orinoco) and the second comprises B. nattereri (upper Paraná), B. opalinus, B. insignis, B. vermelha, B. ferox, Brycon sp., and Henochilus from Brazilian coastal rivers. The sister relationship of B. melanopterus, B. falcatus, 
and B. $c f$. falcatus was expected, as the three species are very similar morphologically. The Brycon species from coastal rivers are also morphologically similar (FCT Lima, pers. comm.). The close relationships among those species inhabiting Brazilian coastal regions is interesting as the Eastern Brazilian coastal rivers were connected many times during the Neogene and Quaternary [63], and ancestor groups may have spread throughout this area.

Based on recently collected specimens, Castro et al. [51] re-described Henochilus wheatlandii and analyzed its relationship with other characiforms using sequences of the genes $12 \mathrm{~S}$ and $16 \mathrm{~S}$. Their results indicated a close relationship between Brycon and Henochilus, as did those of Hilsdorf et al. [60]. Henochilus is morphologically very similar to Brycon and Chilobrycon, with fewer tooth series. This trait may be an autapomorphy of this species [4].

\section{Origin and diversification of Bryconidae groups}

The study of the distribution patterns of freshwater fishes in association with historical biogeography provides an excellent opportunity to test alternative models of evolution of hydrographic basins [64]. Fossil characiforms were described from South America, Africa, Europe, and the Arabian Peninsula [65]. Additionally, a putative characiform fossil was described from Canada [66]. The main lineages of Neotropical freshwater fishes were present in South America by the Lower Cretaceous, and much of their diversification occurred before or during the Paleogene [67-69]. Molecular analyses of Citharinoidei [70] also corroborate the hypotheses of the origin of the order Characiformes as the Lower Cretaceous. Conversely, Eocene-Oligocene articulated specimens of characiforms from the Entre-Córregos Formation, southern Minas Gerais State, eastern Brazil, were described as Tremembichthys sp., cf. Brycon avus, and an undetermined Characidae [71]. More recently, Weiss et al. [72] described two characiforms from this same locality: Paleotetra entrecorregos and $P$. aiuruoca. From the Tremembé Formation (Oligocene), five characiform species were described, all based on articulated specimens: Lignobrycon ligniticus, Megacheirodon unicus, Brycon avus, Cyphocharax mosesi, and Plesiocurimata alvarengai [41]. Two other species, Procharax minor and Lignobrycon altus, were described based on poorly preserved specimens from the Plio-Pleistocene sediments of Nova York shales (northern Brazil) [73].

Using the information available for Lignobrycon ligniticus, that met all suggested points signaled by Parham et al. [39] regarding the use of fossils to calibrate molecular trees, we estimate the origin of the Bryconidae at $46.7 \pm 11.8 \mathrm{Ma}$ (Figure 4), corresponding to the Eocene-Paleocene. According to López-Fernandes and Alberts [69], major marine regressions exposed large areas of interior floodplains during the Oligocene (as in earlier epochs), allowing dramatic and sometimes rapid expansion of freshwater habitats. The formation of the so-called "foreland basin" [74] may have permitted the rapid expansion of a primitive Bryconidae throughout the proto-Paraná and proto-Amazon system.

Within the Bryconidae, clade 1 originated 37.5 \pm 9.7 Ma. This clade is composed of trans-Andean species, including Chilobrycon deuterodon and B. aff. atrocaudatus from Peru, B. henni from Colombia, and Brycon chagrensis and B. petrosus from Panama. The last closure of the Panama Isthmus is generally considered to have occurred between 3.1-2.8 Ma [75,76]. However, some alternative hypotheses regarding faunal exchanges between Central and South America have been proposed. According to Haq et al. [77], during the lower middle Miocene, sea levels were generally very high, but two sea-level drops of almost 100 $\mathrm{m}$ may have occurred between 17 and $15 \mathrm{Ma}$, which could have permitted the migration of fish from South to Central America. Recent geological studies [78,79] suggest that the Panamanian land bridge may be much older (ca. 23-25 Ma). The GAARlandia hypothesis [80] proposes that a geological connection was present between the central part of Central America and South America $32 \mathrm{Ma}$, formed via a land bridge between the Greater Antilles and the Aves Islands Ridge. Finally, a Cretaceous Island Arc [81] has been proposed linking Central America, the Greater Antilles, and South America 80-70 Ma. Some have argued that this Cretaceous Island Arc may have persisted until $49 \mathrm{Ma}$ [82].

Although some previous molecular studies suggest that some primary freshwater fishes from Central America originated after the formation of the Panama landbridge at the end of Tertiary [83,84], an earlier colonization of Mesoamerica has been proposed for other freshwater fishes [85-90]. Additionally, molecular studies of terrestrial taxa support a late Oligocene/early Miocene land connection between Central and South America [91-96]. Thus, although our molecular clock may be limited by the absence of older Bryconidae fossils and, potentially, additional samples, the results obtained are in accordance with an ancient invasion of Central America, dating at least from the origin of the ancestor of $B$. chagrensis, $20.3 \pm 5.0$ $\mathrm{Ma}$ and could be related with the changes in sea level during the lower middle Miocene [77]. However, the hypothesis of multiple invasions, as proposed by Reeves and Bermingham [84], is also in accordance with our data since the ancestor of $B$. petrosus originated at $10.1 \pm 2.8$ Ma (Figure 4).

Clade 2, comprised exclusively of Salminus, originated $29.6 \pm 7.8 \mathrm{Ma}$ (Figure 4). A recent Salminus fossil found in eastern Argentina was dated as from the early late Miocene (Tortonian - 7.1 to 11.2 Ma) [97], consistent with our hypotheses. The first cladogenesis in this group gave origin to the ancestor of $S$. hilarii and the ancestor of the remaining lineages. S. hilarii has a restricted 
distribution in the Upper Paraná and São Francisco Rivers [57]. Our data suggest that the split between lineages of $S$. brasiliensis (in the Paraná, Paraguay and Uruguay River basins and adjacent areas) and $S$. franciscanus (São Francisco River basin) occurred at $5.9 \pm 1.8$ Ma (Figure 4). In his study of Hypostomus, MontoyaBurgos [98] identified a separation time of his samples from the Paraná and São Francisco Rivers (Clade D3) of between 5.7 and 6.4 Ma, a result similar to that of the present study and that of Beurlen (1970; cited by [99]), who suggested that a connection between these basins may have been present from the Tertiary until 1.8 Ma. The cladogenesis that gave origin to Salminus sp. (Amazon basin) and S. affinis (Magdalena River basin) occurred at $3.6 \pm 1.5 \mathrm{Ma}$ (Figure 4). According to Hoorn et al. [99], the most intense periods of formation of the northern Andean mountains occurred from the late middle Miocene $(\sim 12$ $\mathrm{Ma})$ to early Pliocene $(\sim 4.5 \mathrm{Ma})$, a timeframe close to the putative separation time we identified between Salminus $s p$. and S. affinis.

Clade 3, consisting of Brycon pesu, originated $26.7 \pm$ 6.4 Ma. Although this clade is represented by a single species in our study, recent analysis have shown that it is a species complex, composed by several underscribed species (FCT Lima, pers. comm.). This clade is widely distributed throughout the Amazon and Orinoco River basins, as well as in rivers from Guyana, Suriname and French Guiana [59], but our specimens are only from the Amazon basin. Our data suggest a rapid diversification within the last $6.7 \pm 2.0 \mathrm{Ma}$. This period approximately coincides with the final formation of the Amazon and Orinoco drainages [99] and other coastal drainages in north South America. Additional analysis with samples from other drainages and the possible new species will be necessary to better understand the diversification of this group.

Clades 4 and 5 originated $22.3 \pm 6.0 \mathrm{Ma}$. Clade 4 has two main lineages. Brycon moorei (Magdalena River basin) ancestor diverged from the other species at $18.2 \pm$ 4.8 Ma. This old separation time coincides with the first peak of mountain building in the Northern Andes (late Oligocene to early Miocene, approximately $23 \mathrm{Ma}$ ), coinciding with the diversification of the first modern mountain plant and animal genera [99]. Although in our general phylogeny (Figure 3) the remained species in the clade 4 were not statistically well separated in all analyses the Bayesian inference suggest that several lineages originated in different times. Thus, B. orthotaenia (São Francisco River basin) ancestor diverged from the other species of this group at 15.2 $\pm 4.0 \mathrm{Ma}$ (Figure 4). Several authors have suggested that the fish fauna of the São Francisco basin are a hybrid combination of groups from adjacent basins $[100,101]$. Thus, the present data suggest that those connections may have been present since the early Miocene. B. amazonicus (Amazon, Orinoco and Essequibo River basins) ancestor diverged from $B$. hilarii (Paraguay River basin) 12.6 $\pm 3.3 \mathrm{Ma}$ (Figure 4). According to Lundberg et al. [67], the headwater capture of the Upper Paraguay by the Amazonas occurred due to the shift south to the Michicola Arch, 11.8 - 10.0 Ma, a time period very close to that we found. The divergence of $B$. orbygnianus (La Plata River basin) ancestor from B. gouldingi ancestor (Tocantins River basin) $10.7 \pm 3.1 \mathrm{Ma}$ may also have occurred after the shift of the Michicola Arch.

In clade 5, Brycon falcatus (Amazon and Orinoco River basins and rivers in Guyana, Suriname and French Guiana), B. $c f$. falcatus (Culuene River, a tributary of Xingu River) and B. melanopterus (Amazon River basin) ancestors diverged approximately $18.4 \pm 5.2 \mathrm{Ma}$ from the remaining species of this clade that inhabit the ParanáParaguay, São Francisco and coastal rivers in eastern Brazil (Figure 4). This time coincides with the formation of Chapare Buttress, a structural divide that formed between the paleo-Amazonas-Orinoco and Paraguay basins 30 - $20 \mathrm{Ma}$ [67].

The divergence of B. falcatus ancestor from the Orinoco River (sample number 15563) from B. falcatus ancestor from the Negro River (sample number 32395) occurred $4.4 \pm 1.4 \mathrm{Ma}$ (Figure 4). Studies in the Callichthyinae have shown that specimens of Hoplosternum litoralle and Megalechis picta from the Amazon and Orinoco diverged approximately 11.7 to $6 \mathrm{Ma}$, respectively [102]. These data are in accordance with the separation of the Amazon and Orinoco with the formation of Vaupes Arch (late Miocene) and subsequent changes up until the Holocene, when the Andean mountains attained their present configuration [103].

The remaining species in clade 5 are restricted to the Upper Paraná and São Francisco Rivers (Brycon nattereri) and coastal rivers (B. opalinus, Henochilus wheatlandii, B. vermelha, B. insignis, B. ferox and Brycon sp.) and originated 15.1 $\pm 3.9 \mathrm{Ma}$ (Figure 4). In this group, $B$. opalinus from the Paraiba do Sul River is the sister group of the remaining species. This species occurs in the area of the Tremembé formation (Oligocene), where the fossils Brycon avus and Lignobrycon ligniticus were found [41]. Considering B. avus as an Oligocene species it is more possible that it is the sister group of clades 3 to 5 than close relative to the Brycon species that today inhabit the Brazilian coastal area. A future phylogenetic analyses including this species will be necessary to test this hypotheses.

The relationship between the Brycon species of the Amazon and south coastal rivers (clade 5) may be due to the dispersal of a now extinct form from the Paraguay River that dispersed from the south northward into Paraguay and the south coastal rivers as could be B. avus. The other species in this group diverged more recently 
(end of the Miocene and Pliocene), and events such as global climate oscillations and eustatic sea-level fluxes [63] may have produced ancient connections among these coastal rivers, allowing species dispersion and speciation.

In summary, our results align with several geological events in South America, but suggest an old colonization of Central America. However, further studies that include several as yet unsampled Brycon species are necessary to better understand the relationships among some lesser known species such as $B$. coquenani, B. polylepis and $B$. whitei, which could provide new insights into the relationships among Brycon species as well as the origin of some taxa.

\section{Conclusion}

Bryconidae is composed by five main clades, including the genera Brycon, Chilobrycon, Henochilus and Salminus, but a taxonomic review of these groups is needed. Our results points to a possible ancient invasion of Central America, dating about $20.3 \pm 5.0 \mathrm{Ma}$ (late Oligocene/early Miocene), to explain the occurrence of Brycon in Central America.

\section{Additional files}

Additional file 1: Species analyzed, collection number, specimen number, and GenBank accession numbers.

Additional file 2: Sequences of primers used in present study.

\section{Competing interests}

The authors declare that they have no competing interests.

\section{Authors' contribution}

KTA and CO participated equally in the design of the study. KTA and TCM did the most laboratory experiments. KTA and CO analyzed parts of the data and did phylogenetic analyses. All authors discussed results. KTA and CO wrote substantial parts of the manuscript. All authors read and approved the final manuscript.

\section{Acknowledgments}

The authors thank all individuals who assisted us in the collection and identification of the specimens studied here, with special thanks to Dr. Mauro Nirchio, Universidad de Oriente; Hernan Ortega, Museo de Historia Natural, Universidad Nacional Mayor de San Marcos; and Dr. Oris Sanjur, Smithsonian Tropical Research Institute for donations of tissue samples and help with a collection expedition. Special thanks go to Dr. Flávio Lima for his friendly assistance in species identification and thoughtful review and comments on the manuscript. KTA, TCM, and GSA were supported by the Fundação de Amparo à Pesquisa do Estado de São Paulo - FAPESP (06/06749-0, 10/17999-2, 06/05744-4, respectively). CO is a CNPq (Conselho Nacional de Desenvolvimento Científico e Tecnológico do Brasil) researcher (CNPq grant number 309632/2007-2).

Received: 8 April 2014 Accepted: 30 June 2014

Published: 8 July 2014

\section{References}

1. Oliveira C, Avelino GS, Abe KT, Mariguela TC, Benine RC, Ortí G, Vari RP, Castro RMC: Phylogenetic relationships within the speciose family Characidae (Teleostei: Ostariophysi: Characiformes) based on multilocus analysis and extensive ingroup sampling. BMC Evol Biol 2011, 11:275.
2. Eschmeyer WN, Fong JD: Species by family/subfamily. (http://research. calacademy.org/research/ichthyology/catalog/SpeciesByFamily.asp). Electronic version accessed 30/09/2013.

3. Arroyave J, Stiassny MLJ: Phylogenetic relationships and the temporal context for the diversification of African characins of the family Alestidae (Ostariophysi: Characiformes): Evidence from DNA sequence data. Mol Phylogen Evol 2011, 60:385-397.

4. Lima FCT: Subfamily Bryconinae. In Check List of the Freshwater Fishes of South and Central America. Edited by Reis RE, Kullander SO, Ferraris CJ. Porto Alegre: EDIPUCRS; 2003:174-181.

5. Lima FCT: Brycon gouldingi, a new species from the rio Tocantins drainage, Brazil (Ostariophysi: Characiformes: Characidae), with a key to the species in the basin. Ichthyol Explor Freshwaters 2004, 15:279-287.

6. Instituto Brasileiro do Meio Ambiente e dos Recursos Naturais Renováveis: Estatística da pesca 2007: Grandes regiões e unidades da federação. Brasília, Brazil: Ministério do Meio Ambiente; 2007.

7. Eigenmann $\mathrm{CH}$ : The fishes of western South America, Part I. The fresh-water fishes of northwestern South America, including Colombia, Panama, and the Pacific slopes of Ecuador and Peru, together with an appendix upon the fishes of the Rio Meta in Colombia. Mem Carnegie Mus 1922, 9:1-346.

8. Hildebrand SF: A new catalogue of the fresh-water fishes of Panama. Field Mus Nat Hist Publ Zool Ser 1938, 22:219-359.

9. Dahl G: Los peces del norte de Colombia. Instituto de Desarrollo de los Recursos Naturales Renovables (INDERENA). Bogota; 1971.

10. Lima FCT: Revisão taxonômica do gênero Brycon Müller \& Troschel, 1844, dos rios da América do Sul cisandina (Pisces, Ostariophysi, Characiformes, Characidae). Master's thesis: Instituto de Biociências, Universidade de São Paulo, São Paulo; 2001.

11. Regan CT: The classification of the Teleostean fishes of the Order Ostariophysi. - 1. Cyprinoidea. Ann Mag Nat Hist 1911, 8:13-32.

12. Eigenmann $\mathrm{CH}$ : The freshwater fishes of British Guiana, including a study of the ecological grouping of species, and the relation of the fauna of the plateau to that of the lowlands. Mem Carnegie Mus 1912, 5:1-103.

13. Géry J: Poissons characoides nouveaux ou no signalés de I'llha do Bananal, Brésil. Vie et Milieu 1964, 17:448-475.

14. Géry J: Poissons characoides des Guyanes II. Famille des Serrasalmidae. Zool Verband Leiden 1972, 122:134-248.

15. Géry J: Characoids of the world. New Jersey: T.F.H. Publications Inc.; 1977.

16. Roberts T: Osteology and relationships of Characoid fishes, particularly the genera Hepsetus, Salminus, Hoplias, Ctenolucius and Acestrorhynchus. Proc Cal Acad Sci 1969, 36:391-500.

17. Uj A: Etude comparative de l'osteologie cranienne dês poissons de La famille Characidae et son importance phylogenetique. PhD thesis. Faculté des Scienses de l'Université de Genève; 1990.

18. Mirande JM: Phylogeny of the family Characidae (Teleostei: Characiformes): from characters to taxonomy. Neotrop Ichthyol 2010, 8:385-568.

19. Orti G: Radiation of Characiform fishes: evidence from mitochondrial and nuclear DNA sequences. In Molecular Systematics of Fishes. Edited by Kocher TD, Stephien CA. London: Academic Press; 1997:219-243.

20. Calcagnotto D, Schaefer SA, DeSalle R: Relationships among characiform fishes inferred from analysis of nuclear and mitochondrial gene sequences. Mol Phyl Evol 2005, 36:135-153.

21. Javonillo R, Malabarba LR, Weitzman SH, Burns JR: Relationships among major lineages of characid fishes (Teleostei: Ostariophysi: Characiformes), based on molecular sequence data. Mol Phyl Evol 2010, 54:498-511.

22. Hall TA: BioEdit: a user-friendly biological sequence alignment editor and analysis program for Windows 95/98/NT. Nucl Acids Symp Ser 1999, 41:95-98.

23. Edgar RC: MUSCLE: a multiple sequence alignment method with reduced time and space complexity. BMC Bioinformatics 2004, 5:113.

24. Tamura K, Peterson D, Peterson N, Stecher G, Nei M, Kumar S: MEGA5: Molecular Evolutionary Genetics Analysis using Maximum Likelihood, Evolutionary Distance, and Maximum Parsimony Methods. Mol Biol Evol 2011, 28:2731-2739.

25. Xia X, Xie Z: DAMBE: Data analysis in molecular biology and evolution. $J$ Heredity 2001, 92:371-373.

26. Xia X, Xie Z, Salemi M, Chen L, Wang Y: An index of substitution saturation and its application. Mol Phyl Evol 2003, 26:1-7.

27. Xia X, Lemey P: Assessing substitution saturation with DAMBE. In The Phylogenetic Handbook: A Practical Approach to DNA and Protein Phylogeny. 
2nd edition. Edited by Lemey P, Salemi M, Vandamme AM. Cambridge: University Press; 2009:615-630.

28. Li C, Lu G, Ortí G: Optimal data partitioning and a test case for ray-finned fishes (Actinopterygii) based on ten nuclear loci. Syst Biol 2008, 57:519-539.

29. Posada D, Buckley TR: Model selection and model averaging in phylogenetics: advantages of Akaike information criterion and Bayesian approaches over likelihood ratio tests. Syst Biol 2004, 53:793-808.

30. Swofford DL: PAUP*: Phylogenetic analysis using parsimony (*and other methods), Version 4. Sunderland, Massachusetts: Sinauer Associates; 2003.

31. Felsenstein J: Confidence limits on phylogenies: an approach using the bootstrap. Evolution 1985, 39:783-791.

32. Stamatakis A: RAxML-VI-HPC: Maximum likelihood-based phylogenetic analyses with thousands of taxa and mixed models. Bioinformatics 2006, 22:2688-2690

33. Stamatakis A, Hoover P, Rougemont J: A rapid bootstrap algorithm for the RAxML web servers. Syst Biol 2008, 57:758-771.

34. Miller MA, Pfeiffer W, Schwartz T: Creating the CIPRES Science Gateway for inference of large phylogenetic trees. Proc Gat Comp Environm Workshop (GCE) 2010, 1:1-8.

35. Ronquist $F$, Huelsenbeck JP: MrBayes 3: Bayesian phylogenetic inference under mixed models. Bioinformatics 2003, 19:1572-1574.

36. McGuire JA, Witt CC, Altshuler DL, Remsen JV Jr: Phylogenetic systematics and biogeography of hummingbirds: Bayesian and maximum likelihood analyses of partitioned data and selection of an appropriate partitioning strategy. Syst Biol 2007, 56:837-856.

37. Rambaut A, Drummond AJ: Tracer v1.4. 2004. http://beast.bio.ed.ac.uk/ software/tracer.

38. Drummond AJ, Suchard MA, Xie D, Rambaut A: Bayesian phylogenetics with BEAUti and the BEAST 1.7. Mol Biol Evol 2012, 29:1969-1973.

39. Parham JF, Donoghue PCJ, Bell CJ, Calway TD, Head JJ, Holroyd PA, Inoue JG, Irmis RB, Joyce WG, Ksepka DT, Patan JSL, Smith ND, Tarver JE, Van Tuinen M, Yang Z, Angielczyk KD, Greenwood JM, Hipsley CA, Jacobs L, Makovicky PJ, Uller JM, Smith KT, Theodor JM, Warnock RCM, Benton MJ: Best practices for justifying fossil calibrations. Syst Biol 2012, 61:346-359.

40. Eigenmann C, Myers G: The American Characidae. Part 5. Mem Mus Comp Zool 1929, 43:429-558

41. Malabarba MCSL: Phylogeny of fossil Characiformes and paleobiogeography of the Tremembé Formation, São Paulo, Brazil. In Phylogeny and Classification of Neotropical Fishes. Edited by Malabarba LR, Reis RE, Vari RP, Lucena ZMS, Lucena CAS. Porto Alegre: Edipucrs; 1998:69-84.

42. Travassos H, Silva RS: Caracídeos fósseis da Bacia do Paraíba. An Acad Brasil Cienc 1955, 27:297-322.

43. Malabarba MCSL: Sistemática e filogenia dos caraciformes (Actinopterygii: Teleostei) fósseis da Bacia de Taubaté, São Paulo. Unpublished PhD Thesis, Instituto de Geociências, Universidade Federal do Rio Grande do Sul, Porto Alegre, Rio Grande do Sul, Brazi; 1996.

44. Riccomini C, Suguio K, Alvarenga H, Fittipaldi F: Estratigrafia e ambientes de sedimentação da porção central da Bacia de Taubaté. Congr Brasil Paleont 1991, 12:1-29.

45. Soria MF, Alvarenga $\mathrm{H}$ : Nuevos restos de mamiferos de la Cuenca de Taubaté, Estado de São Paulo, Brasil. An Acad Brasil Cienc 1989, 61:157-175.

46. Lima MR, Salard-Cheboldaeff M, Suguio K: Etude palynilogique de la formation Tremembé, Tertiaire du Bassin de Taubaté, (Etat de São Paulo, Bresil), d'apres les echantillons du sondage n-42 du CNP. Coletânea de Trabalhos Paleontológicos, MME-DNPM. Sér zool 1985, 27:379.

47. Rambaut A, Drummond AJ: Tracer v1.5. 2007a. Available from http://beast bio.ed.ac.uk/software/tracer. Accessed 2012 Jan.

48. Rambaut A, Drummond AJ: TreeAnnotator v1.4.8. 2007b. Available from http://beast.bio.ed.ac.uk/software/TreeAnnotator. Accessed 2012 Jan.

49. Li C, Ortí G, Zhang G, Lu G: A practical approach to phylogenomics: The phylogeny of ray-finned fish (Actinopterygii) as a case study. BMC Evol Biol 2007, 7:44

50. Orti $\mathrm{G}$, Meyer $\mathrm{A}$ : The radiation of characiform fishes and the limits of resolution of mitochondrial ribosomal DNA sequences. Syst Biol 1997, 46:75-100.

51. Castro RMC, Vari RP, Vieira F, Oliveira C: A phylogenetic analysis and redescription of the genus Henochilus (Characiformes, Characidae). Copeia 2004, 2004:496-506.

52. Weitzman SH: The osteology and relationships of the South American characoid fishes of the subfamily Gasteropelecinae. Stanford Ichthyol Bull 1954, 4:213-263.
53. Castro RMC, Vari RP: Moojenichthys Miranda-Ribeiro (Pisces: Ostariophysi: Characidae), a phylogenetic reapraisal and redescription. Proc Biol SoC Wash 1990, 103:525-542.

54. Gregory WK, Conrad GM: The phylogeny of the characin fishes. Zoologica 1938, 23:319-360.

55. Eigenmann CH: On the species of Salminus. Ann Carn Mus 1916, 10:91-92.

56. Géry J, Lauzanne L: Les types des espèces du genre Salminus Agassiz, 1829 (Ostariophysi, Characidae) du Muséum National d'Histoire Naturelle de Paris. Cybium 1990, 14:113-124.

57. Lima FCT: Revisão taxonômica e relações filogenéticas do gênero Salminus (Teleostei: Ostariophysi: Characiformes: Characidae). In PhD thesis. São Paulo: Instituto de Biociências, Universidade de São Paulo; 2006.

58. Lima FCT, Britski HA: Salminus franciscanus, a new species from the rio São Francisco basin, Brazil (Ostariophysi: Characiformes: Characidae). Neotrop Ichthyol 2007, 5:237-244.

59. Lima FCT, Malabarba LR, Buckup PA, Silva JFP, Vari RP, Harold A, Benine R, Oyakawa OT, Pavanelli CS, Menezes NA, Lucena CA, Malabarba MCSL, Lucena ZMS, Reis RE, Langeani F, Casatti L, Bertaco VA, Moreira C, Lucinda PHF: Genera Incertae sedis in Characidae. In Check list of the freshwater fishes of South and Central America. Edited by Reis RE, Kullander SO, Ferraris CJ. Porto Alegre: EDIPUCRS; 2003.

60. Hilsdorf AWS, Oliveira C, Lima FCT, Matsumoto CK: A phylogenetic analysis of Brycon and Henochilus (Characiformes: Characidae: Bryconinae) based on the mitochondrial gene 16S rRNA. Genet Mol Biol 2008, 31(Suppl 1):366-371.

61. Géry J, de Rham P: Um nouveau Poisson Characidé endémique du bassin du Rio Tumbès au nord du Pérou, Chilobrycon deuterodon n.g.sp. (Characoidei). Rev Fr Aquariol 1981, 8:7-12.

62. Eigenmann $\mathrm{CH}$ : Some new genera and species of fishes from British Guiana (Repts. of the Expendition to B. Guiana of the Ind. Univer. and Carn. Museum 1908). Ann Carn Mus 1909, 6:4-54.

63. Albert JS, Reis RE: Introduction to Neotropical Freshwaters. In Historical Biogeography of Neotropical Freshwater Fishes. Edited by Albert JS, Reis RE. Berkeley: University of California Press; 2011:3-19.

64. Albert JS, Lovejoy NR, Crampton WGR: Miocene tectonism and the separation of cis- and trans-Andean river basins: Evidence from Neotropical fishes. J S Amer Earth Sci 2006, 21:14-27.

65. Malabarba MCSL, Malabarba LR: Biogeography of Characiformes: an evaluation of the available information of fossil and extant taxa. In Origin and Phylogenetic Interrelationships of Teleosts. Edited by Nelson JS, Schultze H-P, Wilson MVH. München, Germany: Verlag Dr. Friedrich Pfei; 2010:317-336.

66. Newbrey MG, Murray AM, Wilson MVH, Brinkman DB, Neuman AG: Seventyfive-million-year-old tropical tetra-like fish from Canada tracks Cretaceous global warming. Proc R SOC B 2009, 276:3829-3833.

67. Lundberg JG, Marshall LG, Guerrero J, Horton B, Malabarba MCSL, Wesselingh F: The stage for Neotropical fish diversification: a history of tropical South American rivers. In Phylogeny and classification of neotropical fishes. Edited by Malabarba LR, Reis RE, Vari RP, Lucena ZMS, Lucena CAS Porto Alegre: EDIPUCRS; 1998:13-48.

68. Albert JS, Petry P, Reis RE: Major Biogeographic and Phylogenetic Patterns. In Historical Biogeography of Neotropical Freshwater Fishes. Edited by Albert JS, Reis RE. Berkeley: University of California Press; 2011:21-59.

69. Lopez-Fernández H, Albert JS: Paleogene Radiations. In Historical Biogeography of Neotropical Freshwater Fishes. Edited by Albert JS, Reis RE. Berkeley: University of California Press; 2011:105-117.

70. Arroyave J, Denton JSS, Stiassny MLJ: Are characiform Fishes Gondwanan in Origin? Insights from a Time-Scaled Molecular Phylogeny of the Citharinoidei (Ostariophysi: Characiformes). PLOS ONE 2013, 8:e77269.

71. Malabarba MCSL: On the paleoichthyofauna from the Aiuruoca Tertiary Basin, Minas Gerais State, Brazil. Ameghiniana 2004, 41:515-519.

72. Weiss FE, Malabarba LR, Malabarba MC: Phylogenetic relationships of Paleotetra, a new characiform fish (Ostariophysi) with two new species from the Eocene-Oligocene of south-eastern Brazil. J Syst Palaeontol 2012, 10:73-86.

73. Lima MR: Estudo palinológico das "Camadas Nova lorque", Terciário do Estado do Maranhão, Brasil [abstract]. Congr Brasil Paleontol 1991, 12:45.

74. Lima FCT, Ribeiro AC: Continental-scale tectonic controls of biogeography and ecology. In Historical Biogeography of Neotropical Freshwater Fishes. Edited by Albert JS, Reis RE. Berkeley: University of California Press; 2011:145-164 
75. Coates AG, Jackson JBC, Collins LS, Cronin TM, Dowsett HJ, Bybell LM, Jung P, Obando JA: Closure of the Isthmus of Panama: the near-shore marine record of Costa Rica and western Panama. Geol Soc Am Bull 1992, 104:814-828.

76. Coates AG, Obando JA: The geologic evolution of the Central American isthmus. In Evolution and environment in tropical America. Edited by Jackson JBC, Budd AF, Coates AG. Chicago: University of Chicago Press; 1996:21-56.

77. Haq BU, Hardenbol J, Vail PR: Chronology of fluctuating sea levels since the Triassic. Science 1987, 235:1156-1167.

78. Farris DW, Jaramillo C, Bayona G, Restrepo-Moreno SA, Montes C, Cardona A, Mora A, Speakman R, Glascock MD, Valencia V: Fracturing of the Panamanian Isthmus during initial collision with South America. Geology 2011, 39:1007-1010.

79. Montes C, Cardona A, McFadden R, Morón SE, Silva CA, Restrepo-Moreno S, Ramírez DA, Hoyos N, Wilson J, Farris D, Bayona GA, Jaramillo CA, Valencia V, Bryan J, Flores JA: Evidence for middle Eocene and younger land emergence in Central Panama: Implications for Isthmus closure. Geol Soc Am Bull 2012, 124:780-799.

80. Iturralde-Vinent MA, MacPhee RDE: Paleogeography of the Caribbean region: Implications for Cenozoic biogeography. Bull Amer Mus Nat Hist 1999, 238:1-95.

81. Pitman WC III, Cande S, LaBrecque J, Pindell J: Fragmentation of Gondwana: The separation of Africa from South America. In Biological Relationships between Africa and South America. Edited by Goldblatt P. New Haven: Yale University Press; 1993:15-34.

82. Perdices $A$, Bermingham E, Montilla A, Doadrio I: Evolutionary history of the genus Rhamdia (Teleostei: Pimelodidae) in Central America. Mol Phyl Evol 2002, 25:172-189.

83. Strecker U, Faundez VH, Wilkens H: Phylogeography of surface and cave Astyanax (Teleostei) from Central and North America based on cytochrome b sequence data. Mol Phyl Evol 2004, 33:469-481.

84. Reeves RG, Bermingham E: Colonization, population expansion, and lineage turnover: phylogeography of Mesoamerican characiform fish. Biol J Linn Soc 2006, 88:235-255.

85. Murphy WJ, Collier GE: Phylogenetic relationships within the aplocheiloid fi sh genus Rivulus (Cyprinodontiformes, Rivulidae): Implications for Caribbean and Central American biogeography. Mol Biol Evol 2006, 13:642-649.

86. Chakrabarty P: Systematics and historical biogeography of Greater Antillean Cichlidae. Mol Phyl Evol 2006, 39:619-627.

87. Hrbek T, Seckinger J, Meyer A: A phylogenetic and biogeographic perspective on the evolution of poeciliid fishes. Mol Phyl Evol 2007, 43:986-998.

88. Concheiro-Perez GA, Rican O, Orti G, Bermingham E, Doadrio I, Zardoya R: Phylogeny and biogeography of 91 species of heroine cichlids (Teleostei: Cichlidae) based on sequences of the cytochrome b gene. Mol Phyl Evol 2007, 43:91-110.

89. Ornelas-García CP, Domínguez-Domínguez O, Doadrio I: Evolutionary history of the fish genus Astyanax Baird \& Girard (1854) (Actinopterygii, Characidae) in Mesoamerica reveals multiple morphological homoplasies. BMC Evol Biol 2008, 8:340.

90. Rícan O, Piálek L, Zardoya R, Doadrio I, Zrzavy J: Biogeography of the Mesoamerican cichlidae (Teleostei: Heroini): colonization through the GAARlandia land bridge and early diversification. J Biogeogr 2013, 40:579-593.

91. Weigt LA, Crawford AJ, Rand SA, Ryan MJ: Biogeography of the túngara frog, Physalaemus pustulosus: a molecular perspective. Mol Ecol 2005, 14:3851-3876

92. Koepfli K-P, Gompper ME, Eizirik E, Ho C-C, Linden L, Maldonado JE, Wayne RK: Phylogeny of the Procyonidae (Mammalia: Carnivora): molecules, morphology and the Great American Interchange. Mol Phyl Evol 2007, 43:1076-1095.

93. Daza JM, Castoe TA, Parkinson CL: Using regional comparative phylogeographic data from snake lineages to infer historical processes in Middle America. Ecography 2010, 33:343-354.

94. Pinto-Sánchez NR, Ibañez R, Madriñán S, Sanjur OI, Bermingham E, Crawford AJ: The Great American Biotic Interchange in frogs: multiple and early colonization of Central America by the South American genus Pristimantis. Mol Phyl Evol 2012, 62:954-972.

95. Cody S, Richardson JE, Rull V, Ellis C, Pennington RT: The great American biotic interchange revisited. Ecography 2010, 33:326-332.
96. Elmer KR, Bonett RM, Wake DB, Lougheed SC: Early Miocene origin and cryptic diversification of South American salamanders. BMC Evol Biol 2013, 13:59.

97. Cione AL, Azpelicueta MM: The first fossil species of Salminus, a conspicuous South American freshwater predatory fish (Teleostei, Characiformes), found in the Miocene of Argentina. J Vert Paleontol 2013, 33:1051-1060.

98. Montoya-Burgos Jl: Historical biogeography of the catfish genus Hypostomus (Siluriformes: Loricariidae), with implications on the diversification of Neotropical ichthyofauna. Mol Ecol 2003, 12:1855-1867.

99. Hoorn C, Wesselingh FP, ter Steege H, Bermudez MA, Mora A, Sevink J, Sanmartín I, Sanchez-Meseguer A, Anderson CL, Figueiredo JP, Jaramillo C, Riff D, Negri FR, Hooghiemstra H, Lundberg J, Stadler T, Särkinen T, Antonelli A: Amazonia Through Time: Andean Uplift, Climate Change, Landscape Evolution, and Biodiversity. Science 2010, 330:927-931.

100. Vari RP: The Curimatidae, a lowland Neotropical fish family (Pisces: Characiformes); distribution, endemism, and phylogenetic biogeography. In Proceedings of a Workshop on Neotropical Distribution Patterns. Edited by Vanzolini PE, Heyer WR. Rio de Janeiro: Academia Brasileira de Ciências; 1988:343-377

101. Lima FCT, Caires RA: Peixes da Estação Ecológica Serra Geral do Tocantins, bacias dos Rios Tocantins e São Francisco, com observações sobre as implicações biogeográficas das "águas emendadas" dos Rios Sapão e Galheiros. Biota Neotrop 2011, 11:231-250.

102. Mariguela TC, Alexandrou MA, Foresti F, Oliveira C: Historical biogeography and cryptic diversity in the Callichthyinae (Siluriformes, Callichthyidae). J Zoolog Syst Evol Res 2013, 51:308-315.

103. Hoorn C, Guerrero J, Sarmiento GA, Lorente MA: Andean Tectonics as a Cause for Changing Drainage Patter in Miocene Northern South-America. Geology 1995, 23:237-240.

doi:10.1186/1471-2148-14-152

Cite this article as: Abe et al: Systematic and historical biogeography of the Bryconidae (Ostariophysi: Characiformes) suggesting a new rearrangement of its genera and an old origin of Mesoamerican ichthyofauna. BMC Evolutionary Biology 2014 14:152.

\section{Submit your next manuscript to BioMed Central and take full advantage of:}

- Convenient online submission

- Thorough peer review

- No space constraints or color figure charges

- Immediate publication on acceptance

- Inclusion in PubMed, CAS, Scopus and Google Scholar

- Research which is freely available for redistribution 